\title{
Polypodiaceae da borda oeste do Pantanal sul-matogrossense, Brasil
}

\author{
ELTON LUIS MONTEIRO DE ASSIS ${ }^{1}$ e PAULO HENRIQUE LABIAK ${ }^{2,3}$
}

(recebido: 29 de novembro de 2007; aceito: 5 de fevereiro de 2009)

\begin{abstract}
Polypodiaceae from the west border of Pantanal, Brazil). In this paper is presented the taxonomic treatment for the species of Polypodiaceae from the west border of Brazilian Pantanal. The family is represented by 14 species, corresponding to the genera Pecluma (four species), Pleopeltis (three species), Campyloneurum, Microgramma and Phlebodium (two species each), and Serpocaulon (one specie). Identification keys, descriptions of genera and species, illustrations, geographic distribution, and comments on the closest species are presented.
\end{abstract}

Key words - ferns, Pantanal, Polypodiaceae, taxonomy

RESUMO - (Polypodiaceae da borda oeste do Pantanal sul-matogrossense, Brasil). Este trabalho apresenta o tratamento taxonômico para as espécies de Polypodiaceae da região da borda oeste do Pantanal sul-matogrossense. A família está representada por 14 espécies, distribuídas nos gêneros Pecluma (quatro espécies), Pleopeltis (três espécies), Campyloneurum, Microgramma e Phlebodium (duas espécies cada) e Serpocaulon (uma espécie). São apresentados chaves de identificação, descrições dos gêneros e espécies, ilustrações, bem como dados sobre a distribuição geográfica e comentários sobre as espécies mais semelhantes.

Palavras-chave - Pantanal, Polypodiaceae, samambaias, taxonomia

\section{Introdução}

Polypodiaceae constitui uma das maiores famílias de samambaias, com aproximadamente 56 gêneros e 1.200 espécies (Smith et al. 2006), a maioria ocorrendo em áreas de florestas tropicais úmidas. Em uma recente publicação sobre a classificação do grupo, Smith et al. (2006) apresentaram uma nova e ampla circunscrição para a família, incluindo nesta alguns grupos frequentemente segredados em famílias distintas (como por exemplo Grammitidaceae).

Não obstante a diversidade desta família seja reconhecidamente maior em áreas úmidas, esta constitui também um dos grupos mais ricos de espécies em ambientes mais secos, como nas regiões Centro-Oeste e Nordeste do Brasil (Barros et al. 2004; Labiak 2005). Apesar da diversidade de pteridófitas da região CentroOeste, verifica-se uma carência de trabalhos que forneçam subsídios ao reconhecimento desta flora. Isso é particularmente verdade para o Estado do Mato Grosso do Sul, uma das áreas menos estudadas da região e que, pela singularidade dos ambientes que apresenta, é de extrema importância no contexto florístico regional.

\footnotetext{
1. Parte da dissertação de mestrado do primeiro autor. Programa de Pós-Graduação em Botânica, Universidade Federal do Paraná.

2. Universidade Federal do Paraná, Departamento de Botânica. Caixa Postal 19031, 81531-980 Curitiba, PR.

3._Autor para correspondência:plabiak@ufpr.br
}

Para a região Centro-Oeste do Brasil, mais especificamente para o Estado de Mato Grosso, destaca-se uma série de trabalhos publicados por Windisch (1975, 1985, 1994, 1995, 1996, 1997, 1998), Windisch \& Nonato (1999), Windisch \& Tryon (2001) e Athayde Filho \& Windisch (2003), nos quais são apresentados tratamentos taxonômicos para algumas famílias de pteridófitas e uma análise da diversidade presente no Estado. Embora tais trabalhos sejam extremamente relevantes no contexto regional, as características distintas entre o Pantanal e o Cerrado do Brasil Central tornam difícil a apreciação da diversidade de pteridófitas esperada para a região em questão, tendo como base apenas os trabalhos supracitados. Ademais, Polypodiaceae é uma das famílias ainda não monografadas para o Estado de Mato Grosso, o que reforça ainda mais a necessidade de estudos sobre este grupo na região.

Dessa forma, pretende-se apresentar o tratamento taxonômico para Polypodiaceae, que é uma das famílias mais diversas no Pantanal brasileiro, contribuindo não só para o conhecimento da área em questão, mas também fornecendo subsídios para a identificação dos táxons presentes em áreas adjacentes.

\section{Material e métodos}

A área de estudo, denominada borda oeste do Pantanal, situa-se na bacia do Alto Paraguai, nos Municípios de Corumbá, Ladário e Porto Murtinho, MS, entre as coordenadas 
$17^{\circ} 24^{\prime}, 1^{\circ} 25^{\prime} \mathrm{S}$ e $57^{\circ} 22^{\prime}, 57^{\circ} 58^{\prime} \mathrm{W}$. É limitada a Oeste pela fronteira entre o Brasil e a Bolívia, a Leste pelas regiões da Nhecolândia e Paiaguás, ao Norte pelos morros residuais pertencentes às morrarias do Amolar, na divisa com o Estado de Mato Grosso, e ao Sul de Corumbá pelo Maciço do Urucum e de Coimbra (Isquierdo 1997).

O complexo Pantanal, no qual a região estudada está inserida, possui ambientes bastante distintos, variando desde planícies de inundação, contendo vegetação inundável com áreas de matas ciliares, até morrarias de $1.065 \mathrm{~m}$ de altitude, que apresentam diferentes tipologias vegetacionais como florestas semideciduais e deciduais, cerradão e campos de altitude, além de incorporar elementos das províncias fitogeográficas adjacentes, como a Floresta Amazônica e o Chaco (Adamoli 1982, Bortolotto et al. 1996).

O clima é do tipo tropical semi-úmido sazonal, com duas estações definidas, um semestre de inverno seco e outro de verão chuvoso (Cadavid-Garcia 1984). A precipitação pluvial média é de $1.070 \mathrm{~mm} / \mathrm{ano}$, sendo os meses de novembro e março os mais chuvosos.

O levantamento florístico foi realizado nos anos de 2004 a 2006, seguindo as técnicas padrão para o grupo, e os materiais estão depositados nos herbários COR e UPCB. Duplicatas, quando disponíveis, foram enviadas aos herbários BHCB, MBM, SI e SP. Materiais adicionais provenientes da Bolívia (USZ) foram também analisados e comparados com os materiais da área em estudo, com vistas à complementação das descrições no que se refere às variações morfológicas observadas.

Para a apresentação dos táxons foi adotado o sistema de classificação proposto por Smith et al. (2006). Os sinônimos, bem como as informações sobre a distribuição geográfica, foram baseados em literatura especializada e em observações dos próprios autores. A abreviação dos autores de nomes de espécies segue Pichi-Sermolli (1996).

\section{Resultados e discussão}

Polypodiaceae J. Presl \& C. Presl, Delic. Prag. 159. 1822. Tipo: Polypodium L.

Plantas terrestres, epífitas ou rupícolas. Caule vertical ou horizontal, curto a longo-reptante, rígido, escamoso. Frondes $3 \mathrm{~cm}$ a $2 \mathrm{~m}$ compr., inteiras, pinatífidas ou variavelmente divididas ou pinadas, monomorfas ou dimorfas, glabras ou pubescentes; pecíolo articulado com o caule, formando filopódios; estípulas ausentes; nervuras livres ou anastomosadas, com ou sem vênulas inclusas. Lâmina simples a várias vezes dividida; nervuras simples ou várias vezes furcadas, livres ou anastomosadas, com ou sem vênulas inclusas às aréolas; soros arredondados a alongados, surgindo ao longo ou na extremidade de uma nervura, ou na junção de duas nervuras, ou o esporângio crescendo em uma comissura vascular ou em uma rede especial de nervuras férteis, sem indúsio, paráfises presentes ou ausentes; esporângios com o pedicelo formado de 1 a 2 (3) fileiras de células, ânulo vertical e interrompido pelo pedicelo; esporos monoletes ou triletes, com ou sem clorofila.

Polypodiaceae é uma das famílias mais ricas em número de espécies na área de estudo. Pode ser distinguida das demais famílias presentes na região por apresentar o pecíolo articulado com o caule (formando filopódios), o caule horizontal e os soros arredondados. Com exceção de alguns gêneros (anteriormente tratados em Grammitidaceae e ausentes na área abordada neste trabalho), uma característica também marcante para a família é a presença de esporos monoletes amarelados.

Chave para os gêneros de Polypodiaceae da borda oeste do Pantanal sul-matogrossense

1. Lâmina inteira; soros não recobertos por escamas peltadas

2. Soros geralmente em duas fileiras entre as nervuras laterais principais, subsidiados por apenas uma nervura ................................................................................................ 1. Campyloneurum

2. Soros em uma fileira entre as nervuras laterais principais, subsidiados por mais de uma nervura

2. Microgramma

1. Lâmina pinatissecta ou mais dividida; se inteira, com escamas peltadas recobrindo os soros

3. Lâmina revestida por escamas peltadas, geralmente recobrindo completamente o tecido laminar; soros geralmente recobertos por paráfises na forma de escamas peltadas

5. Pleopeltis

3. Lâmina sem escamas peltadas ou, quando presentes, nunca recobrindo completamente o tecido laminar; soros nunca recobertos por paráfises na forma de escamas peltadas

4. Nervuras livres ou, se anastomosadas, sem vênulas inclusas nas aréolas 3. Pecluma

4. Nervuras anastomosadas, com vênulas inclusas nas aréolas

5. Nervuras regularmente anastomosadas; soros surgindo sobre uma única nervura inclusa.

6. Serpocaulon

5. Nervuras irregularmente anastomosadas; soros surgindo no ápice da confluência de duas nervuras inclusas 
1. Campyloneurum C. Presl, Tent. Pterid.: 189. 1836. Lectótipo: Polypodium repens Aubl. (= Campyloneurum repens (Aubl.) C. Presl.)

Plantas epífitas, raramente terrícolas ou rupícolas. Caule curto a longo-reptante, simples ou ramificado, com escamas castanhas, freqüentemente clatradas, peltadas ou basifixas, glabras; frondes monomorfas, agrupadas ou distantes entre si; pecíolo ausente a longo, estramíneo a castanho-escuro; lâmina inteira, linear a elíptico-lanceolada, cartácea a coriácea, glabra ou moderadamente pubescente, quando pubescente, com tricomas simples a ramificados; nervuras anastomosadas, com uma ou várias fileiras de aréolas, formadas pela junção das nervuras principais com as nervuras laterais secundárias, produzindo $2 \mathrm{ou}$ mais nervuras inclusas, livres, simples ou furcadas, às vezes uma terceira nervura excurrente que, em alguns casos, divide completamente a aréola. Soros arredondados, subsidiados por apenas uma nervura, surgindo logo abaixo ou no ápice das nervuras inclusas, geralmente em duas fileiras entre as nervuras laterais principais; paráfises quando presentes, simples ou ramificadas; esporângios glabros; esporos monoletes, verrucosos, com depósitos esféricos.

Chave para as espécies de Campyloneurum da borda oeste do Pantanal sul-matogrossense

1. Lâmina linear, com até $0,8 \mathrm{~cm}$ larg.

1.1. C. centrobrasilianum

1. Lâmina elíptico-lanceolada, com mais $7 \mathrm{~cm}$ de larg. 1.2. C. phyllitidis

1.1. Campyloneurum centrobrasilianum Lellinger, Amer. Fern J. 78(1):16. 1988.

Figura $1 \mathrm{~A}-\mathrm{C}$

Plantas epífitas. Caule curto-reptante, $c a .2,5 \mathrm{~mm}$ diâm., com escamas deltóide-lanceoladas, $c a .4 \mathrm{~mm}$ compr., castanho-claras, células da porção central estreitamente oblongas, regulares, as da base retangulares, contorcidas, ápice longo-acuminado, base peltada, cordiforme, margem inteira ou levemente denteada; frondes $35-55 \mathrm{~cm}$ compr., agrupadas entre si; pecíolo estramíneo, 0,3-0,5 mm compr., levemente sulcado na face adaxial, glabro; filopódio $c a$. $1 \mathrm{~mm}$ compr.; lâmina inteira, linear, $32-56 \times 0,3-0,8 \mathrm{~cm}$, coriácea, ápice longoacuminado, base atenuada, margem inteira, revoluta, glabra em ambas as faces; costa glabra; nervuras anastomosadas, as primárias levemente conspícuas, formando um ângulo de $c a$. de $85^{\circ}$ com a costa, aréolas em duas séries irregulares entre a costa e a margem, com 1 vênula inclusa, simples, nervuras secundárias inconspícuas. Soros supramedianos, dispostos em uma série entre a margem e a costa; paráfises ausentes; esporos elipsóides a reniformes, levemente verrucosos.

Material examinado: BRASIL. MAto Grosso Do Sul: Corumbá, Morro Santa Cruz, 19²4'49” S, 59²2'47” W, 10-X-2003, E.L.M. Assis et al. 453 (COR, MBM, SP, UPCB).

Distribuição geográfica: endêmica do Brasil (GO, DF, MG, MS).

Campyloneurum centrobrasilianum se caracteriza por apresentar a lâmina linear e as escamas do caule deltóide-lanceoladas, ápice longo-acuminado, base peltada e margem inteira a levemente denteada, com as células da porção central oblongas e regulares, e as da base retangulares e contorcidas. Dentre as espécies que apresentam a lâmina linear, Campyloneurum aglaolepis (Alston) de la Sota, $C$. angustifolium (Sw.) Fée e $C$. austrobrasilianum (Alston) de la Sota são as mais semelhantes, distingüindo-se por apresentar as escamas do caule com células da base não contorcidas, como nesta espécie. Segundo Lellinger (1988) esta espécie é também semelhante a $C$. angustipaleatum (Alston) $\mathrm{M}$. Meyer ex Lellinger, que difere por apresentar as escamas do caule lineares.

1.2. Campyloneurum phyllitidis (L.) C. Presl, Suppl. Tent. Pterid. 190. 1836 三 Polypodium phyllitidis L., Sp. Pl. 2:1083. 1753.

Figura 1D-F

Plantas epífitas ou rupícolas. Caule curto-reptante, $c a .7$ mm diâm., com escamas deltóide-lanceoladas, $c a$. 4,5 mm compr., castanho-escuras, células da porção central oblongas, regulares, as marginais contorcidas ou transversais, ápice acuminado, base peltada, cordiforme, margem inteira; frondes 90-130 cm compr., agrupadas entre si; pecíolo estramíneo, 1-4 cm compr., sulcado na face adaxial, glabro; filopódio ca. 5 mm compr.; lâmina inteira, elíptico-lanceolada, 90-130×7-10 cm, subcoriácea, ápice acuminado, base atenuada, margem inteira, sinuosa, não revoluta, glabra em ambas as faces; costa glabra; nervuras anastomosadas, as primárias conspícuas, formando um ângulo de $c a$. de $65^{\circ}$ com a costa, aréolas em 12 séries entre a costa e a margem, com 2 vênulas inclusas simples e uma terceira ou quarta estéreis que subdividem completamente a aréola primária, nervuras 


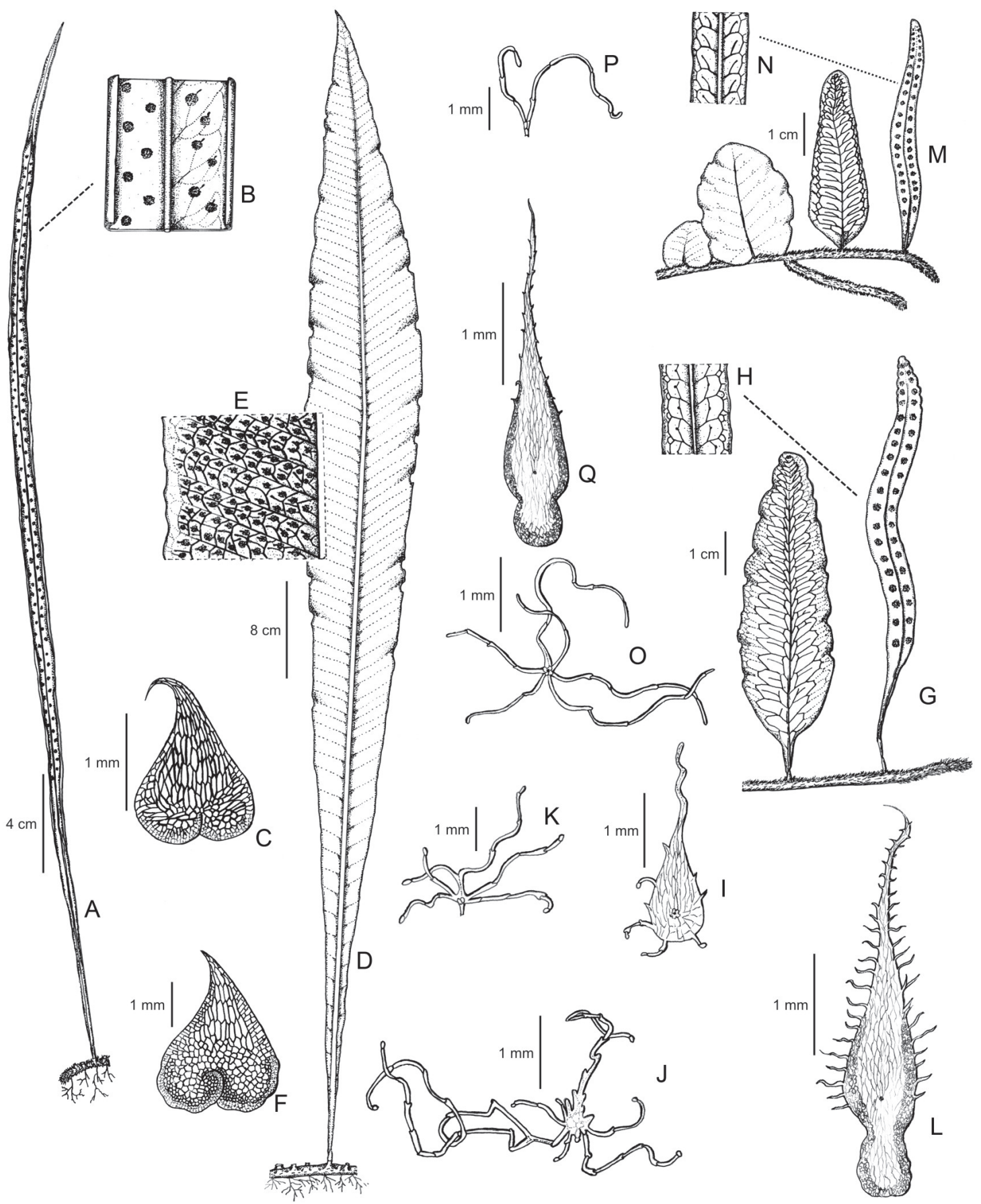

Figura 1. A-C. Campyloneurum centrobrasilianum (E.L.M. Assis et al. 453, COR). A. Hábito. B. Detalhe da lâmina. C. Escama do caule. D-F. Campyloneurum phyllitidis (E.L.M. Assis 216, COR). D. Hábito. E. Detalhe das nervuras. F. Escama do caule. G-L. Microgramma mortoniana (E.L.M. Assis \& P. Shwartsburd 548, COR). G. Hábito. H. Detalhe das nervuras. I. Escama da lâmina. J. Escama da lâmina. K. Paráfise. L. Escama do caule. M-Q. Microgramma vacciniifolia (E.L.M. Assis et al. 208, COR). M. Hábito. N. Detalhe das nervuras. O. Escama da lâmina. P. Paráfise. Q. Escama do caule.

Figure 1. A-C. Campyloneurum centrobrasilianum (E.L.M. Assis et al. 453, COR). A. Habit. B. Detail of the lamina. C. Scale of the rhizome. D-F. Campyloneurum phyllitidis (E.L.M. Assis 216, COR). D. Habit. E. Detail of the veins. F. Scale of the rhizome. G-L. Microgramma mortoniana (E.L.M. Assis \& P. Shwartsburd 548, COR). G. Habit. H. Detail of the veins. I. Scale of the lamina. J. Scale of the lamina. K. Paraphyses. L. Scale of the rhizome. M-Q. Microgramma vacciniifolia (E.L.M. Assis et al. 208, COR). M. Habit. N. Detail of the veins. O. Scale of the lamina. P. Paraphyses. Q. Scale of the rhizome. 
secundárias levemente conspícuas. Soros supramedianos dispostos em 8-10 séries entre a margem e a costa; paráfises ausentes; esporos elipsóides a reniformes, levemente verrucosos.

Material examinado: BRASIL. Mato Grosso do SUL: Corumbá, Morro Santa Cruz, 19²4'49” S, 59²2'47” W, 22-VII-1999, E.L.M. Assis et al. 54 (BHCB, COR); Idem, Morro Urucum, Córrego Banda Alta, 19¹1'15" S, 57³4'53" W, 7-VI-2001, E.L.M. Assis 216 (COR, MBM, SP, UPCB).

Material adicional examinado: BOLÍVIA. SANTA Cruz: Vellasco, Parque Nacional Noel Kempff Mercado, 1334'15" S, 61 01'19" W, 7-VI-1994, L. Arroyo \& J. Wellens 792 (USZ); Idem, Flórida, Samaipata, 18¹2’ S, 6350’ W, 1-V-1994, M. Rojas \& G. Vargas 1994 (USZ).

Distribuição geográfica: Estados Unidos (Flórida), México, Guatemala, Belize, Honduras, Costa Rica, Panamá, Antilhas, Guiana, Suriname, Guiana Francesa, Colômbia, Equador, Peru, Bolívia e Brasil (PA, RR, AC, GO, DF, MS) (Mickel \& Smith 2004; Labiak 2005).

Esta espécie se caracteriza por apresentar a lâmina elíptico-lanceolada, podendo atingir até 1,3 m de compr., as escamas do caule com as células marginais contorcidas ou transversais, ápice acuminado, base peltada e margem inteira.

Segundo Lellinger (1988), Campyloneurum phyllitidis apresenta venação regular, com três vênulas inclusas. No entanto, o material examinado apresentou
3-4(-5) vênulas inclusas, sendo que as aréolas primárias são subdivididas por estas ou, quando completamente dividas, as aréolas secundárias não são isodiamétricas.

Ocorre principalmente como epífita em Floresta Estacional Semidecidual, próxima a córregos, acima de $800 \mathrm{~m}$ de altitude.

2. Microgramma C. Presl, Tent. Pterid.: 213. 1836. Tipo: Polypodium persicariifolium Schrad. (= Microgramma persicariifolia (Schrad.) C. Presl).

Plantas epífitas ou raramente rupícolas. Caule longo-reptante, delgado, ramificado, com escamas alvas, castanhas na região da inserção, não clatradas, peltadas, glabras; frondes monomorfas a dimorfas, distantes entre si; pecíolo ausente a curto, estramíneo a castanho, não sulcado, com escamas densas ou esparsas; lâmina inteira, oval a oblonga ou linear, cartácea a subcoriácea, glabra a moderadamente escamosa, com escamas filamentosas ou arredondadas; costa esparsa a densamente escamosa; nervuras anastomosadas, com aréolas costais freqüentemente maiores que as demais, portando 1 ou mais nervuras inclusas, livres ou novamente anastomosadas; soros arredondados a alongados, subsidiados por mais de uma nervura, surgindo no ápice ou na junção das nervuras inclusas em apenas uma série entre a costa e a margem; paráfises presentes, filiformes; esporângios glabros; esporos monoletes, verrucosos, rugosos ou tuberculados.

Chave para as espécies de Microgramma da borda oeste do Pantanal sul-matogrossense

1. Lâmina cartácea, aréolas costais incompletas, sem vênulas inclusas, escamas do caule ciliadas 2.1. M. mortoniana

1. Lâmina coriácea, aréolas costais completas, com vênulas inclusas, escamas do caule denteadas 2.2. $M$ vacciniifolia

2.1. Microgramma mortoniana de la Sota, Amer. Fern. J. 63:64. 1973.

Figura 1G-L

Plantas epífitas, raramente rupícolas. Caule longoreptante, $c a$. 6 mm diâm., com escamas oval-lanceoladas, peltadas, $c a .8 \mathrm{~mm}$ compr., alvas, castanho-escuras no ponto de inserção, ápice filiforme, base auriculada, aurícula irregularmente arredondada, margem ciliada; frondes dimorfas, 4-10,5 cm compr., distantes entre si; pecíolo estramíneo, ca. $1 \mathrm{~mm}$ compr., escamoso; filopódio ca. $1 \mathrm{~mm}$ compr.; lâmina estéril oval-lanceolada, 4-9,5 $\times$ 1,2-2 cm, cartácea, ápice obtuso a agudo, base cuneada, margem inteira, sinuosa, escamas dendríticas, longamente ciliadas, presentes sobre ambas as faces; costa com escamas esparsas iguais as da lâmina; nervuras anastomosadas, terminado livres próximo à margem, 1-3(-4) séries de aréolas, sendo a de maior comprimento com 1 vênula inclusa livre, furcada ou anastomosante, as costais geralmente incompletas, sem vênulas inclusas; lâmina fértil linear, 6,5-10,5 × 6-10 cm, cartácea, ápice obtuso, base atenuada, margem inteira, glabra ou com escamas esparsas iguais as da lâmina estéril; nervuras anastomosadas, (1-)2 séries de aréola com 1 vênula inclusa livre ou furcada, aréolas costais geralmente incompletas, conspícuas, sem vênulas inclusas; soros medianos dispostos em 1 série entre a costa e a margem da lâmina; paráfises filiformes, ramificadas; esporos reniformes, tuberculados. 
Material examinado: BRASIL. Mato Grosso do Sul: Corumbá, Margem do Rio Paraguai, 1759’29” S, 57²9’21” W, 4-VIII-2005, E.L.M. Assis \& P. Swartsburd 528 (COR); Idem, Morro Santa Cruz, 19²4’49" S, $59^{\circ} 22^{\prime} 47 ” \mathrm{~W}$, 5-VIII-2005, E.L.M. Assis \& P. Schwartsburd 548 (COR).

Distribuição geográfica: Bolívia, Paraguai, Argentina e Brasil (MS).

Microgramma mortoniana se caracteriza por apresentar aréolas costais incompletas, sem vênulas inclusas ou, quando presentes, restritas as aréolas subcostais, além das escamas do caule ciliadas. Estas características a diferem da outra espécie encontrada na região, além da textura coriácea da lâmina e paráfises pouco ramificadas de $M$. vaccicniifolia.

Sota (1973) considera Microgramma mortoniana como tendo uma origem híbrida entre $M$. vacciniifolia e M. squamulosa (Kauf.) de la Sota, com base nas dimensões dos estômatos e esporos, tornando-se fértil por meio da duplicação de seus cromossomos (poliploidia).

Microgramma squamulosa difere principalmente por apresentar três ou mais vênulas inclusas nas aréolas.

Esta espécie até momento havia sido relatada apenas para a Argentina, Paraguai e Bolívia (Sota 1973), sendo este o primeiro registro para o Brasil. Na área de estudo ocorre como epífita em Floresta Estacional Semidecídual, acima de $80 \mathrm{~m}$ de altitude.

2.2. Microgramma vacciniifolia (Langsd. \& Fisch.) Copel., Gen. fil.: 85. 1947 Polypodium vacciniifolium Langsd. \& Fisch., Icon. fil.: 8. 1810.

Figura $1 \mathrm{M}-\mathrm{Q}$

Plantas epífitas, raramente rupícolas. Caule longoreptante, $c a .3 \mathrm{~mm}$ diâm., com escamas oval-lanceoladas, peltadas, $c a .7 \mathrm{~mm}$ compr., alvas, castanho-escuras na região de inserção, ápice filiforme, base auriculada, aurícula irregularmente arredondada, margem denteada; frondes dimorfas, 1,5-9 cm compr., distantes entre si; pecíolo ausente a conspícuo, estramíneo, 0,5 mm compr., escamoso; filopódio ca. $1 \mathrm{~mm}$ compr.; lâmina estéril oval, elíptica ou oblonga, $1-4 \times 0,6-1,2 \mathrm{~cm}$, coriácea, ápice arredondado, base cordada a cuneada, margem inteira, levemente ondulada, escamas dendríticas presentes sobre ambas as faces; costa com escamas iguais as da lâmina, densas ou esparsas; nervuras anastomosadas, livres apenas nas proximidades da margem, 1-3 séries de aréolas com 1 vênula inclusa nas aréolas costais, livres ou furcadas; lâmina fértil linear, 2,5-9 × 0,3-0,5 cm, coriácea, ápice obtuso, base atenuada, margem inteira, com escamas esparsas iguais às da lâmina estéril; nervuras anastomosadas, 1(-2) séries de aréolas com uma vênula inclusa, livre, exceto nas distais quando presentes, conspícuas. Soros medianos, dispostos em uma série entre a costa e a margem da lâmina; paráfises filiformes, pouco ramificadas; esporos reniformes, verrucosos.

Material examinado: BRASIL. MATO GROSSO DO SuL: Corumbá, Morro Santa Cruz, 19²4'49” S, 59²2'47” W, 6-IX-1999, E.L.M. Assis et al. 56 (BHCB, COR); Idem, Ilha Ínsua (Reserva Indígena dos Guatós), 7-V-2001, E.L.M. Assis et al. 131 (COR); Idem, Morro Santa Cruz, 07-VI-2001, E.L.M. Assis et al. 207 (COR); Idem, id., 7-VI-2001, E.L.M. Assis et al. 208 (COR); Ladário, Morro Urucum, 26-VII-2001, E.L.M. Assis 272 (COR); Idem, id., 16-IX-1989, Bueno 118 (CPAP).

Distribuição geográfica: Paraguai, Argentina e Brasil (PE, BA, MG, ES, RJ, SP, MS, PR, SC, RS) (Mickel \& Smith 2004; Labiak \& Prado 1998).

Microgramma vaccinifolia se caracteriza por apresentar um dimorfismo bastante acentuado, com a fronde estéril podendo variar de oval a elíptica, ou ainda oblonga, e a fronde fértil linear, com uma acentuada diminuição no número de aréolas (geralmente até três séries de aréolas nas estéreis e apenas uma nas férteis).

Segundo Sota (1960), esta espécie pode ser confundida com Microgramma squamulosa (Kaulf.) de la Sota, a qual difere por apresentar as aréolas costais mais complexas, divididas em 1-5 aréolas com 1-3 vênulas inclusas.

Ocorre em Floresta Estacional Semidecidual como epífitas ou rupícolas, acima de $700 \mathrm{~m}$ de altitude.

3. Pecluma M. G. Price, Amer. Fern J. 73:109. 1983. Tipo: Polypodium pectinatum L. (= Pecluma pectinata (L.) M. G. Price).

Plantas epífitas ou raramente terrícolas. Caule curto a longo-reptante, não ramificado, frequentemente com raízes prolíficas, com escamas, castanhas, basifixas, não clatradas, superfície glabra ou pilosa; frondes monomorfas, agrupadas ou distantes entre si; pecíolo curto a longo, castanho-escuro a negro, cilíndrico, glabro a pubescente; lâmina oblonga ou lanceolada, profundamente pinatissecta, herbácea a coriácea, pubescente; raque e costa pilosas e/ou moderadamente escamosas; segmentos lineares a estreitamente lanceolados, margem inteira; nervuras livres, simples ou furcadas, raramente anastomosadas; soros arredondados, surgindo no ápice das nervuras livres ou no ápice das vênulas inclusas em apenas uma série entre a costa e a margem do segmento; paráfises simples, clavadas ou furcadas; esporângios glabros ou setosos; esporos frequentemente bilaterais, tuberculados. 
Chave para as espécies de Pecluma da borda oeste do Pantanal sul-matogrossence

1. Nervuras proximais anastomosadas

3.3. P. macedoi

1. Nervuras proximais livres

2. Nervuras simples 3.2. P. filicula

2. Nervuras 1-2(-3)-furcadas

3. Segmentos basais fortemente reduzidos, auriculiformes 3.4. P. plumula

3. Segmentos basais reduzidos apenas à metade do comprimento dos demais, não auriculiformes

3.1. Pecluma dispersa (A. M. Evans) M. G. Price, Amer. Fern J. 73:114. $1983 \equiv$ Polypodium dispersum A. M. Evans, Amer. Fern J. 58:173, tab. 27. 1968.

Figura 2A-C

Plantas epífitas. Caule curto-reptante, ca. $5 \mathrm{~mm}$ diâm., com escamas deltóide-lanceoladas, $c a .3,5 \mathrm{~mm}$ compr., castanho-escuras, ápice longo-acuminado, base peltada, cordiforme, basifixas, levemente ciliadas, margem inconspicuamente denticulada; frondes $25-75 \mathrm{~cm}$ compr., agrupadas entre si; pecíolo negro, 6-11 cm compr., superfície adaxial densamente revestida por tricomas aciculares, a abaxial glabrescente; filopódio $c a .2 \mathrm{~mm}$ compr.; lâmina pinatissecta, estreitamente deltóidelanceolada, 19-64 ×4-7 cm, subcoriácea, ápice atenuado, base com segmentos reduzidos à metade do comprimento dos demais, não auriculiformes, reflexos, face adaxial glabrescente, face abaxial pubescente, tricomas castanhoclaros, simples; raque pubescente, face abaxial com escamas deltóides de base ciliada; costa pubescente, com escamas lineares na face abaxial; segmentos estreitamente lanceolados, 2-3,5 × 0,2-0,4 cm, ápice arredondado a acuminado, ascendentes a perpendiculares a costa, margem inteira com tricomas castanho-claros, os segmentos proximais levemente reduzidos, deflexos; nervuras 2-furcadas, inconspícuas; soros supramedianos; paráfises simples, clavadas; esporângios setosos; esporos monoletes, levemente tuberculados.

Material examinado: BRASIL. MAto Grosso Do Sul: Corumbá, Morro Santa Cruz, 19²4'49”' S e 59²2'47” W, 10-X-2003, E.L.M. Assis et al. 455 (COR, UPCB).

Distribuição geográfica: Sul dos Estados Unidos (Flórida), México, Guatemala, Honduras, Nicarágua, Costa Rica, Panamá, Antilhas, Colômbia, Venezuela, Equador, Peru, Bolívia e Brasil (CE, MG, RJ, MT, MS,) (Evans 1969).

Pecluma dispersa difere de P. plumula, uma das espécies mais semelhantes, por apresentar os segmentos basais reduzidos até a metade do comprimento dos demais, reflexos. De acordo com Evans (1969), P. dispersa é triplóide e os espécimes brasileiros provavelmente representariam um híbrido entre $P$. filicula e $P$. plumula, podendo apresentar um ciclo de vida apogâmico, formando densas populações de plantas estéreis (ver comentários adicionais em $P$. plumula).

3.2. Pecluma filicula (Kaulf.) M. G. Price, Amer. Fern J. 73:114. $1983 \equiv$ Polypodium filicula Kaulf., Enum. fil.: 275. 1824 .

Figura 2D-G

Plantas epífitas, ocasionalmente rupícolas. Caule curto-reptante, ca. 1,5 mm diâm., com escamas cordiformes, $c a .1 \mathrm{~mm}$ compr, castanho-escuras, ápice longo-acuminado a filiforme, base peltada, cordada, margem inteira; frondes 5-15 cm compr., agrupadas entre si; pecíolo castanho-escuro, 0,5-2 cm compr., densamente revestido por tricomas simples; filopódio $c a .0,5 \mathrm{~mm}$ compr.; lâmina pinatissecta, elíptico-lanceolada, 4,5-13 $\times 1-2 \mathrm{~cm}$, herbácea a coriácea, ápice e base atenuados, face adaxial glabrescente, face abaxial pubescente; raque pubescente com escamas cordiformes na face abaxial; costa pubescente em ambas as faces; segmentos lineares, 4-7 $\times 0,1-0,2 \mathrm{~cm}$, os segmentos proximais reduzidos a aurículas, ápice obtuso, ascendentes, margem inteira, com tricomas castanho-claros, sinuosa; nervuras livres, simples, inconspícuas; soros supramedianos; paráfises simples, clavadas; esporângios glabros; esporos monoletes, tuberculados.

Material examinado: BRASIL. Mato Grosso DO Sul: Corumbá, Morro Urucum (Córrego Banda Alta), 19¹1'15" S, 57³4'53" W, 14-II-2001, E.L.M. Assis et al. 89 (BHCB, COR); Idem, id., 5-VI-2001, E.L.M. Assis et al. 191 (COR, MBM, UPCB); Idem, Morro Santa Cruz (Faz. Paraíso), 19²4’49” S, 59²2’47” W, 11-XI-2001, E.L.M. Assis et al. 313 (COR, SP).

Material adicional examinado: BOLÍVIA. SANTA Cruz: Florida, Cerro Herradura, $18^{\circ} 67^{\prime} \mathrm{S}, 6^{\circ} 36^{\prime} \mathrm{W}$, 20-III-1998, M. Nee et al. (USZ).

Distribuição geográfica: Colômbia, Peru, Bolívia, Paraguai, Argentina e Brasil (MG, RJ, SP, MT, MS, PR, SC, RS) (Evans 1969 - em parte). 


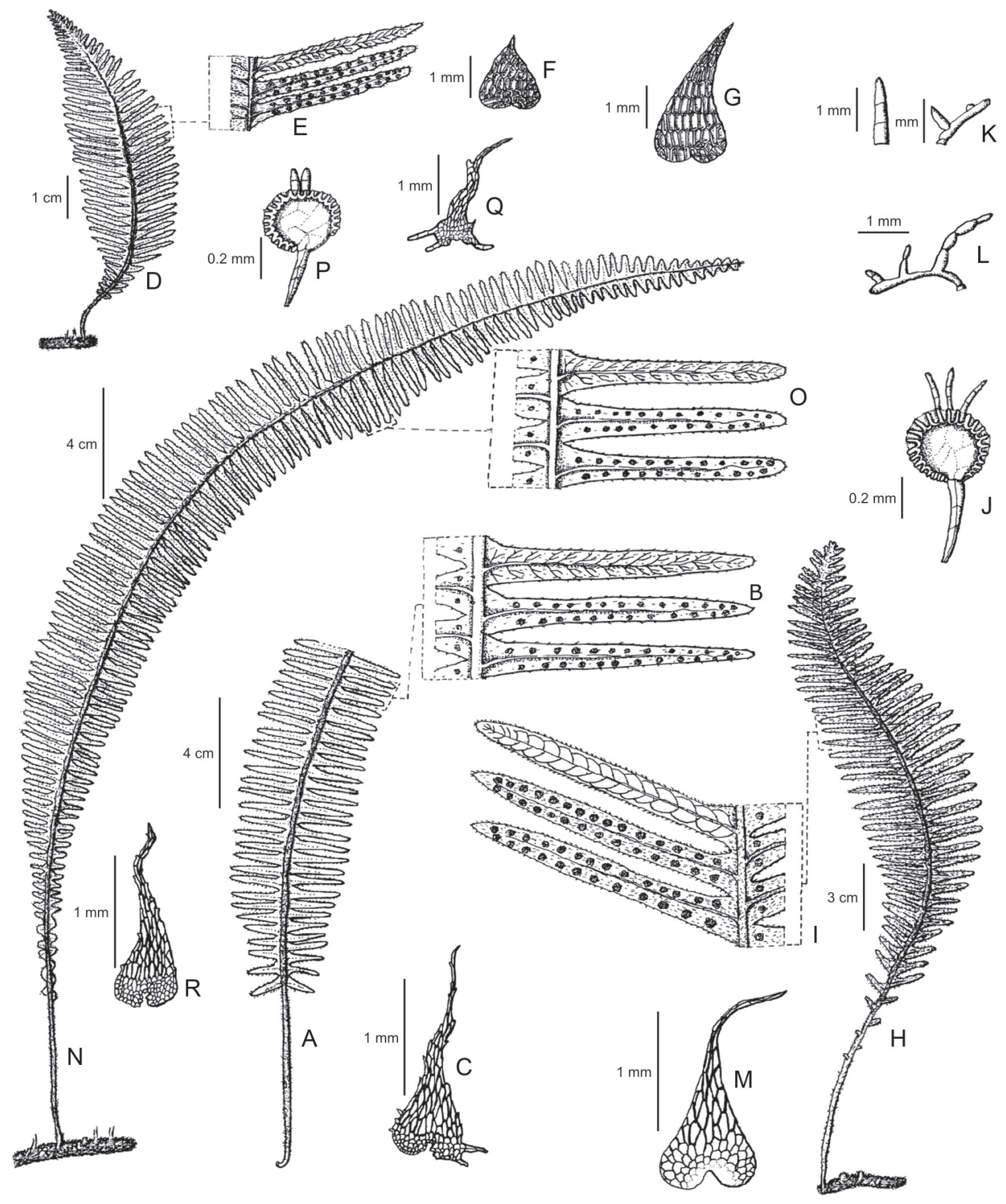

Figura 2. A-C. Pecluma dispersa (E.L.M. Assis et al. 455, COR). A. Porção basal da fronde. B. Segmento, face abaxial. C. Escama raque. D-G. Pecluma filicula (E.L.M. Assis et al. 316, COR). D. Hábito. E. Pina. F. Escama da raque. G. Escama do caule. H-M. Pecluma macedoi (E.L.M. Assis et al. 273, COR). H. Hábito. I. Porção mediana da lâmina. J. Esporângio. K. Paráfises. L. Tricoma do pecíolo. M. Escama do caule. N-R. Pecluma plumula (E.L.M. Assis \& P. Schwartsburd 547, COR). N. Hábito. O. Segmentos. P. Esporângio. Q. Escama da costa. R. Escama da raque.

Figure 2. A-C. Pecluma dispersa (E.L.M. Assis et al. 455, COR). A. Basal portion of the frond. B. Abaxial surface of the segment. C. Scale of the rachises. D-G. Pecluma filicula (E.L.M. Assis et al. 316, COR). D. Habit. E. Pinnae. F. Scale of the rachises. G. Scale of the rhizome. H-M. Pecluma macedoi (E.L.M. Assis et al. 273, COR). H. Habit. I. Medial portion of the frond. J. Sporangium. K. Paraphyses. L. Hair of the petiole. M. Scale of the rhizome. N-R. Pecluma plumula (E.L.M. Assis \& P. Schwartsburd 547, COR). N. Habit. O. Segments. P. Sporangium. Q. Scale of the costae. R. Scale of the rachises. 
Pecluma filicula se caracteriza pelo pequeno tamanho da fronde (até $15 \mathrm{~cm}$ compr.) e pelas escamas cordiformes presentes na raque. Embora seja citada na literatura (Sehnem 1970, Evans 1969) como apresentando apenas nervuras simples, no material examinado também foram observadas nervuras furcadas. Esta característica pode ser variável nesta espécie, bem como a consistência da lâmina (herbácea a coriácea), como observado por Sota (1960) para os espécimes da Argentina.

Esta espécie é semelhante a Pecluma truncorum (Lindm.) M. G. Price, que difere pelo tamanho maior da lâmina (maior que $20 \mathrm{~cm}$ compr.) e pela ausência de escamas na raque. Ocorre na região como epífita em no interior de Floresta Estacional Semidecudual, acima de $600 \mathrm{~m}$ de altitude.

3.3. Pecluma macedoi (Brade) M. Kessler \& A. R. Sm., Candollea 60(1):281. $2005 \equiv$ Polypodium macedoi Brade, Arch. Jard. Bot. Rio de Janeiro 11:30. $1951 \equiv$ Polypodium camptophylarium var. macedoi Evans, Ann. Missouri Bot. Gard. 55(3):254. $1969 \equiv$ Pecluma camptophyllaria var. macedoi (Brade) A. Salino, Novon 8:296. 1998.

Figura 2H-M

Plantas rupícolas ou terrícolas, ocasionalmente epífitas. Caule curto-reptante, ca. $7 \mathrm{~mm}$ diâm., com escamas deltóide-lanceoladas, ca. 4 mm compr., castanho-escuras, ápice filiforme, basifixa, cordiforme, margem inteira a levemente denteada; frondes $15-60 \mathrm{~cm}$ compr., agrupadas entre si; pecíolo castanho-escuro, 5-22 cm compr., glabrescente, tricomas catenados presentes; filopódio $c a .5 \mathrm{~mm}$ compr.; lâmina elípticolanceolada, 12-48 cm compr. × 6-14 cm larg., herbácea, ápice agudo, base abruptamente reduzida, auriculiformes, densamente pubescente em ambas as faces, tricomas furcados e catenados presentes próximos aos soros; raque densamente pilosa em ambas as faces, tricomas pluricelulares, escamas ausentes; costa densamente pilosa e com escamas lineares, esparsas; segmentos estreitamente deltóide-lanceolados, 3,5-7 cm ×0,3-0,6 cm, ascendentes, ápice obtuso a levemente acuminado, margem com tricomas alvos, os segmentos proximais reduzidos a aurículas; nervuras proximais anastomosadas, sem vênulas inclusas, as distais livres, furcadas, conspícuas; soros medianos; paráfises simples, clavadas ou ramificadas; esporângios ciliados; esporos reniformes, tuberculados.

Material examinado: BRASIL. MAto Grosso do Sul: Corumbá, Morro Urucum, (nascente do Córrego Banda Alta), 19¹1'15" S, 57³4'53” W, 16-VII-1999, E.L.M.
Assis et al. 40 (BHCB, COR); Idem, id., 5-VI-2001, E.L.M. Assis et al. 191 (COR, MBM, UPCB); Idem, id., 26-VI-2001, E.L.M. Assis et al. 273 (COR, SP, UPCB).

Distribuição geográfica: Bolívia e Brasil (MG, SP, MS) (Evans 1969, Kessler \& Smith 2005).

Pecluma macedoi se caracteriza por apresentar os segmentos proximais reduzidos à metade das demais, ou formando arurículas, pelos tricomas da lâmina alvos, densos, furcados, e pelas nervuras proximais anastomosadas, sem vênulas inclusas nas aréolas.

É semelhante a Pecluma pectinata (L.) M. G. Price, a qual difere por apresentar o pecíolo castanhoavermelhado, as escamas do caule esparsamente ciliadas, pelas paráfises simples, clavadas, além dos esporângios glabros.

Ocorre em Floresta Estacional Semidecidual, em ambientes sombreados e úmidos, como terrícolas ou rupícolas sobre rochas com muita matéria orgânica, raro como epífita, geralmente acima de $850 \mathrm{~m}$ de altitude.

3.4. Pecluma plumula (Humb. \& Bonpl. ex Willd.) M. G. Price, Amer. Fern J. 73:115. $1983 \equiv$ Polypodium plumula Humb. \& Bonpl. ex Willd., Sp. Pl., ed. 4, 5(1): 178. 1810.

Figura 2N-R

Plantas epífitas, ocasionalmente rupícolas. Caule curto-reptante, ca. $5 \mathrm{~mm}$ diâm., com escamas deltóides, ca. 4,5 mm compr., castanho-escuras, ápice longoacuminado, basifixa, cordada, ciliada ou não, margem papilada; frondes 20-65 cm compr., agrupadas entre si; pecíolo negro, 3-5 cm compr., glabrescente a pubescente; filopódio ca. $2 \mathrm{~mm}$ compr.; lâmina estreitamente elípticolanceolada, $15-59 \times 3-5 \mathrm{~cm}$, subcoriácea, ápice e base atenuados, base com segmentos auriculiformes, face adaxial glabrescente, face abaxial pubescente, tricomas castanho-claros, aciculares; raque pubescente, ttricomas semelhantes aos da lâmina, face abaxial com escamas deltóides, base ciliada; costas pubescentes em ambas as faces e com escamas lineares na face abaxial; segmentos lineares, 1,2-2,5 $\mathrm{cm} \times 0,2-0,3 \mathrm{~mm}$, ápice obtuso, perpendiculares à costa, margem com tricomas castanhoclaros, os segmentos proximais reduzidos a aurículas; nervuras livres, 1-furcadas, inconspícuas; soros supramedianos; paráfises simples, clavadas; esporângios setosos, setas curtas; esporos monoletes, tuberculados.

Material examinado: BRASIL. Mato Grosso DO Sul: Corumbá, Morro Santa Cruz, 19²4'49" S, 59²2'47”' W, 29-V-1999, E.L.M. Assis et al. 71 (COR); Idem, id., 5-VII-2005, E.L.M. Assis \& Schwartsburd 547 (COR). 
Material adicional examinado: BOLÍVIA. SANTA Cruz: Ichilo, $17^{\circ} 21^{\prime}$ S, 6406' W, s.d., M. Nee 48405 (USZ).

Distribuição geográfica: Estados Unidos (Flórida), México, Guatemala, Belize, Honduras, Nicarágua, Panamá, Venezuela, Trinidad, Suriname, Guiana Francesa, Colômbia, Equador, Peru, Bolívia e Brasil (AM, CE, PE, BA, MG, RJ, SP, MS) (Evans 1969 - em parte).

Pecluma plumula se caracteriza por apresentar a lâmina estreitamente elíptico-lanceolada, segmentos lineares perpendiculares à costa, e os proximais reduzidos a aurículas. É semelhante a $P$. dispersa, mas difere principalmente por esta última apresentar esporos globosos. Segundo Evans (1969), P. dispersa tem uma origem provavelmente híbrida, com reprodução apogâmica, enquanto $P$. plumula é tetraplóide, com ciclo de vida normal.

Os dois táxons também diferem em relação à margem da escama do caule e nervação: em $P$. dispersa as escamas são inconspicuamente denticuladas e as nervuras 2-furcadas, em oposição a P. plumula que possui as escamas papiladas e nervuras 1-furcadas.
Ocorre em Floresta Estacional Semidecidual, em ambientes úmidos, acima de $800 \mathrm{~m}$ de altitude.

4. Phlebodium (R. Br.) J. Sm., J. Bot. (Hooker) 4:58. 1841. Tipo: Polypodium sect. Phlebodium R. Br. in Horsfiled, Pl. Jav. Rar. 4:1838.

Plantas epífitas, rupícolas ou ocasionalmente terrícolas. Caule horizontal, curto a longo-reptante, com escamas castanhas a castanho-douradas, não clatradas, peltadas, glabras. Frondes monomorfas, distantes entre si; pecíolo longo, estramíneo a castanho-escuro, sulcado na face adaxial, lâmina pinatissecta, oblonga a subdeltóide, herbácea a coriácea, glabra ou com tricomas esparsos, frequentemente glauca na face abaxial; costa e nervuras glabras; segmentos lanceolados, margem inteira; nervuras anastomosadas, com 2 ou mais nervuras inclusas, livres ou confluentes em seus ápices, aréolas costais sem nervuras inclusas; soros arredondados, surgindo no ápice da confluência de duas ou mais nervuras inclusas, em 1-8 séries entre a cóstula e a margem do segmento; paráfises ausentes; esporângios glabros; esporos bilaterais, tuberculados a verrucosos.

Chave para as espécies de Phlebodium da borda oeste do Pantanal sul-matogrossense

1. Soros em 3-8 séries entre a margem e a costa

4.1. P. decumanum

1. Soros em apenas uma série entre a margem e a costa..... 4.2. P. pseudoaureum

4.1. Phlebodium decumanum (Willd.) J. Sm., Bot. (Hooker) 4:59. 1841 三 Polypodium decumanum Willd., Sp. Pl., ed. 4, 5(1):170. 1810.

Figura 3F-H

Plantas epífitas ou rupícolas. Caule longo-reptante, ca. $4 \mathrm{~cm}$ diâm., com escamas lanceoladas, ca. $2 \mathrm{~cm}$ compr., castanho-avermelhadas, ápice filiforme, base arredondada, margem curto-ciliada; frondes $60-140 \mathrm{~cm}$ compr., distantes entre si; pecíolo castanho-claro a castanho-escuro, 20-40 cm compr., sulcado na face abaxial, glabro; filopódio $5 \mathrm{~mm}$ compr:; lâmina pinatissecta, lanceolada, 40-100 × 30-55 cm, herbácea, ápice agudo, base truncada, glabra ou com tricomas, castanho-claros, esparsos; raque e costa glabras ou com tricomas iguais aos da lâmina; segmentos lanceolados, 18-46 cm × 2,5$6,5 \mathrm{~cm}$, ascendentes, ápice acuminado, margem inteira, ondulada, segmentos proximais não reduzidos; nervuras irregularmente anastomosadas, em 5-8 séries de aréolas, conspícuas; soros medianos, dispostos em 3-8 séries entre a costa e a margem do segmento; esporângios glabros; esporos reniformes, verrucosos.
Material examinado: BRASIL. Mato Grosso do SuL: Corumbá, Morro Santa Cruz, 19²4'49” S, 59²2’47” W, 29-V-1999, E.L.M. Assis et al. 4 (BHCB, COR); Idem, Região do Amolar (córrego Zé Dias), 2752'08” S, 57³1'26” W, 5-V-2001, E.L.M. Assis et al. 125 (COR); Corumbá, Morro Urucum (nascente do córrego Banda Alta), 19¹1'15" S, 57³4'53" W, 5-VI-2001, E.L.M. Assis et al. 188 (COR, UPCB); Idem, Faz. São João, 12-VI-2001, E.L.M. Assis et al. 246 (COR, MBM, SP, UPCB); Corumbá, Morro Urucum, 23-IX-1989, Bueno et al. 82 (CPAP); Idem, id., 1-V-1996, G.A. Damasceno Junior et al. 1048 (COR).

Material adicional examinado: BOLÍVIA. SANTA CruZ: Ichilo, $17^{\circ} 14^{\prime}$ S, 635'' W, 21-XII-1995, M. Nee 46419 (USZ); Idem, Nuflo de Chávez, Lomerio, $16^{\circ} 31^{\prime}$ S, 61ํ5' W, 16-III-1995, A. Jardim \& G. Musaso 1786 (USZ).

Distribuição geográfica: Estados Unidos (Flórida), México, Guatemala, Honduras, Venezuela, Trinidad, Suriname, Guiana Francesa, Colômbia, Equador, Peru, Bolívia, Paraguai, Argentina, Uruguai, Brasil (PE, BA, MG, RJ, SP, MT, MS) (Mickel \& Smith 2004 - em parte). 

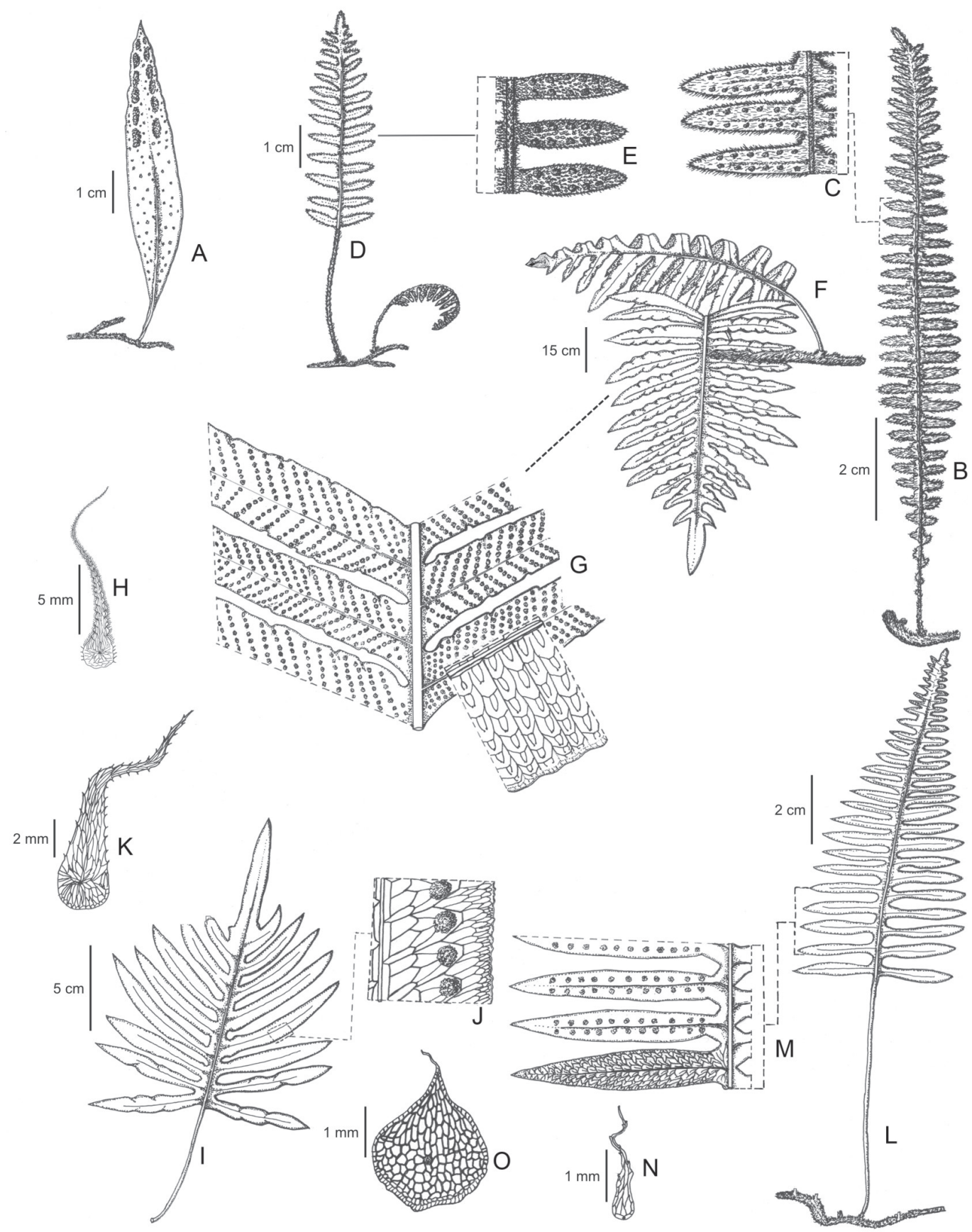

Figura 3. A. Pleopeltis astrolepis (E.L.M. Assis et al. 206, COR), Hábito. B-C. Pleopeltis hirsutissima (E.L.M. Assis et al. 467, COR). B. Hábito. C. Segmento, face abaxial. D-E. Pleopeltis squalida (E.L.M. Assis et al. 236, COR). D. Hábito. E. ISegmento, face abaxial. F-H. Phlebodium decumanum (E.L.M. Assis et al. 246, COR). F. Hábito. G. Posição dos soros e nervuras. H. Escama do caule. I-K. Phlebodium pseudoaureum (E.L.M. Assis et al. 460, COR). I. Hábito. J. Detalhe dos soros e nervuras. K. Escama do caule. L-O. Serpocaulon vacillans (E.L.M. Assis et al. 462, COR). L. Hábito. M. Segmentos, soros e nervuras. N. Escama da raque e costa. O. Escama do caule.

Figure 3. A. Pleopeltis astrolepis (E.L.M. Assis et al. 206, COR), Habit. B-C. Pleopeltis hirsutissima (E.L.M. Assis et al. 467, COR). B. Habit. C. Abaxial surface of the segment. D-E. Pleopeltis squalida (E.L.M. Assis et al. 236, COR). D. Habit. E. Abaxial surface of the segment. F-H. Phlebodium decumanum (E.L.M. Assis et al. 246, COR). F. Habit. G. Sori and veins. H. Scale of the rhizome. I-K. Phlebodium pseudoaureum (E.L.M. Assis et al. 460, COR). I. Habit. J. Detail of the sori and veins. K. Scale of the rhizome. L-O. Serpocaulon vacillans (E.L.M. Assis et al. 462, COR). L. Habit. M. Detail of the segments, sori and veins. N. Scale of the rachises and costae. O. Scale of the rhizome. 
Esta espécie se caracteriza pelo grande tamanho da fronde, frequentemente maior que $1 \mathrm{~m}$ de comprimento, pela presença de tricomas castanho-claros, sobre o tecido laminar, junto à costa e nervuras, escamas do caule curto-ciliadas na margem, castanho-avermelhadas, e por apresentar 3-8 fileiras de soros em cada lado da costa.

Ocorre em Floresta Estacional Semidecidual, sendo bastante comum como epífita sobre palmeira Scheelea phalerata (Mart.) Bur. (acuri). Seu caule longo-reptante costuma abraçar o forófito chegando a um comprimento de $60 \mathrm{~cm}$, sendo também comum a queda das frondes nos períodos de seca. Na região de estudo ocorre acima de $300 \mathrm{~m}$ de altitude.

4.2. Phlebodium pseudoaureum (Cav.) Lellinger, Amer. Fern J. 77:101. 1987 $\equiv$ Polypodium pseudoaureum Cav., Descr. Pl.: 247. 1802.

Figura 3I-K

Plantas epífitas ou rupícolas. Caule curto a longoreptante, ca. $8 \mathrm{~mm}$ diâm., com escamas deltóidelanceoladas, $c a .8 \mathrm{~mm}$ compr., castanho-escuras, ápice longo-acuminado, base arredondada, margem denticulada; frondes 30-60 cm compr., distantes entre si; pecíolo castanho-escuro, 10-20 cm compr., sulcado na face adaxial, glabro; filopódio $c a .3 \mathrm{~mm}$ compr.; lâmina deltóide-lanceolada, profundamente pinatissecta, 25-40 $\times 10-25 \mathrm{~cm}$, cartácea, ápice agudo, base truncada, face abaxial com cera esbranquiçada próxima a raque e costa, glabra; raque e costa glabras; segmentos lanceolados, 5,5-15 × 1,5-2,5 cm, ápice obtuso, ascendentes, margem inteira, ondulada, os segmentos proximais não reduzidos, levemente deflexos; nervuras anastomosadas com $2(-3)$ séries de aréolas, cada uma com 1-3(-4) vênulas inclusas, conspícuas; soros medianos, dispostos em uma fileira entre a costa e a margem do segmento; esporângios glabros; esporos reniformes, verrucosos.

Material examinado: BRASIL. Mato Grosso do Sul: Corumbá, Morro Santa Cruz, 19²4'49" S, 59²2'47” W, 30-VII-1999, E.L.M. Assis et al. 48 (BHCB, COR); idem, id., 5-II-2002, E.L.M. Assis et al.
337 (COR); Idem, id., 1-VII-2004, E.L.M. Assis et al. 460 (COR).

Material adicional examinado: BOLÍVIA. SANTA CRUZ: Vellasco, Parque Nacional Noel Kempff Mercado, Campamento Las Ganas, 1448’ S, 60²3’ W, 4-VIII-1993, L. Arroyo et al. 207 (USZ).

Distribuição geográfica: Estados Unidos (Flórida), México, Guatemala, Honduras, El Salvador, Nicarágua, Panamá, Venezuela, Trinidad, Guiana, Suriname, Guiana Francesa, Colômbia, Equador, Peru, Bolívia, Norte da Argentina e Brasil (BA, MG, RJ, SP, MT, MS, PR, SC) (Mickel \& Smith 2004 - em parte).

Phlebodium pseudoaureum se caracteriza por apresentar o pecíolo, lâmina, costa e cóstulas essencialmente glabros, e por ter apenas uma fileira de soros entre a costa e a margem dos segmentos.

Esta espécie ocorre em Floresta Estacional Semidecidual, acima de $800 \mathrm{~m}$ de altitude, sendo comum em locais sombreados e rara em ambientes abertos.

5. Pleopeltis Humb. \& Bonpl. ex Willd., Sp. Pl., ed. 4, 5(1):211. 1810. Tipo: Pleopeltis angusta Humb. \& Bonpl. ex Willd.

Plantas epífitas ou ocasionalmente rupícolas. Caule horizontal, longo-reptante, ramificado, com escamas castanhas, clatradas ou não, peltadas, superfície glabra ou pilosa; frondes monomorfas, agrupadas ou distantes entre si; pecíolo curto a longo, castanho-escuro a negro, não sulcado, cilíndrico ou aplanado adaxialmente, glabro a escamoso; lâmina inteira, pinatissecta a pinado-pinatífida, lanceolada a deltóide-lanceolada, coriácea, esparsa a densamente revestida por escamas peltadas, circulares, deltóides a gonfóides; raque ou costa e cóstulas escamosas; segmentos lanceolados a estreitamente deltóide-lanceolados, com margem inteira; nervuras anastomosadas, com 1-3 vênulas inclusas livres, furcadas ou anastomosadas; soros arredondados a oblongos, recobertos por escamas peltadas, surgindo na junção das vênulas inclusas em uma série entre a margem e a costa da lâmina; paráfises filiformes, ou na forma de escamas peltadas, ou ausentes; esporângios glabros; esporos bilaterais, verrucosos.

Chave para as espécies de Pleopeltis da borda oeste do Pantanal sul-matogrossense

1. Lâmina inteira, com escamas circulares a ovais, esparsas, tecido laminar visível; soros alongados ...... 5.1. P. astrolepis

1. Lâmina pinatissecta, com escamas deltóides a gonfóides, densas, tecido laminar recoberto pelas escamas, raramente visível; soros arredondados.

2. Caule com mais de 2 mm de diâm.; lâmina com 20-30 pares de segmentos, escamas gonfóides presentes na lâmina

5.2. P. hirsutissima

2. Caule com até 1,5 mm de diâm.; lamina com 6-15 pares de segmentos, escamas gonfóides ausentes 
5.1. Pleopeltis astrolepis (Liebm.) E. Fourn., Mexic. Pl. 1:87. $1872 \equiv$ Polypodium astrolepis Liebm., Mexic. Bregn.: 185 (reprint 33). 1849.

Figura 3A

Plantas epífitas. Caule longo-reptante, ca. $1 \mathrm{~mm}$ diâm., com escamas circulares a ovais, $c a$. $0,5 \mathrm{~mm}$ compr., clatradas, negras da porção central e castanhoescuras na margem, com tricomas castanho-escuros na região de inserção, ápice acuminado, base arredondada, margem denteada; frondes monomorfas, $6-15 \mathrm{~cm}$ compr., distantes entre si; pecíolo negro, 0,5-1 cm compr., achatado, glabro ou com escamas ovais; filopódio $c a$. 0,4 mm compr.; lâmina inteira, linear-lanceolada, 5,5-14 $\times 0,7-1 \mathrm{~cm}$, subcoriácea a coriácea, ápice acuminado, base atenuada, margem inteira, com escamas circulares a ovais em ambas as faces, tecido laminar visível entre as escamas; costa escamosa, escamas iguais às da lâmina; nervuras anastomosadas, com 4 séries de aréolas com 2-3 vênulas inclusas que se anastomosam, inconspícuas; soros medianos, ausentes na parte proximal da lâmina, alongados, dispostos em 1 fileira entre a margem e a costa; paráfises filiformes; esporângios glabros; esporos reniformes, verrucosos.

Material examinado: BRASIL. MATO GRosso do SuL: Corumbá, Morro Santa Cruz, 19²4'49”' S, 59²2’47” W, 29-V-1999, E.L.M. Assis et al. 24 (BHCB, COR); Idem, Morro Urucum (Córrego Banda Alta), 19¹1'15" S, 57³4'53” W, 7-VI-2001, E.L.M. Assis et al. 206 (COR, MBM, SP, UPCB); Idem, Morro Santa Cruz, 19²4’49” S, 59²2' 47' W, 2-XI-2001, E.L.M. Assis et al. 319 (COR).

Distribuição geográfica: Estados Unidos (Flórida), México, Guatemala, Honduras, Nicarágua, Costa Rica, Panamá, Antilhas, Venezuela, Trinidad, Suriname, Guiana Francesa, Colômbia, Equador, Peru, Bolívia e Brasil (PE, BA, MG, RJ, SP, MS, PR, SC) (Mickel \& Smith 2004; Labiak \& Prado 1998).

Espécie caracterizada pela lâmina inteira e pelos soros alongados, localizados distalmente na lâmina, o que a distingue das demais espécies presentes na região.

$\mathrm{Na}$ área estudada ocorre como epífita nas Florestas Estacional Semidecidual e Decidual, acima de $150 \mathrm{~m}$ de altitude.

5.2. Pleopeltis hirsutissima (Raddi) de la Sota, Darwiniana 45(2):239. 2008 三 Polypodium hirsutissimum Raddi, Opusc. Sci. Bol. 3:286. 1819.

Figura 3B-C

Plantas epífitas ou ocasionalmente terrícolas. Caule curto-reptante, ca. 4 mm diâm., com escamas lanceoladas a deltóide-lanceoladas, $c a$. $7 \mathrm{~mm}$ compr., castanho-escuras na porção central e castanho-claras na margem, ápice filiforme, base arredondada, margem ciliada; frondes monomorfas, $25-40 \mathrm{~cm}$ compr., agrupadas entre si; pecíolo estramíneo, 1-5 cm compr., cilíndrico, com escamas iguais as do caule; filopódio $c a .2 \mathrm{~mm}$ compr.; lâmina pinatissecta, elíptico-lanceolada, 25-35 × 2,5-3,5 cm, coriácea, ápice agudo, base atenuada, ambas as faces recobertas por escamas gonfóides e deltóide-lanceoladas, peltadas, as da face adaxial alvas e castanho-escuras no ponto de inserção, as da face abaxial castanho-claras, ambas com a margem ciliada, as próximas dos soros ovais, imbricadas, com a margem ciliada; costa escamosa em ambas as faces, escamas castanho-escuras, estreitamente deltóides; cóstulas escamosas, escamas iguais as da costa, inconspícuas; 20 -30 pares de segmentos deltóidelanceolados, 1,5-2,5 $\times 0,3-0,5 \mathrm{~cm}$, ápice agudo, margem inteira, aeróforos presentes na base acroscópica dos segmentos, segmentos proximais reduzidos a aurículas; nervuras anastomosadas, com uma fileira de aréola, com uma vênula inclusa livre, inconspícuas; soros medianos dispostos em uma fileira entre a margem e a costa da lâmina, protegidos lateralmente por um anel de escamas; paráfises ausentes; esporângios glabros; esporos reniformes, verrucosos.

Material examinado: BRASIL. Mato Grosso do Sul: Corumbá, Morro Santa Cruz, 19²4'49” S, 59²2'47' W, 6-IX-1999, E.L.M. Assis \& Rodriguez 54 (BHCB, COR); Idem, id. 18-VII-1999, E.L.M. Assis et al. 58 (COR, UPCB), Idem, id., 1-VII-2004, E.L.M. Assis et al. 467 (COR, MBM).

Material adicional examinado: BOLÍVIA. SANTA Cruz: Carrasco, 1700’ S, 64²4’ W, 24-X-1991, L. Arroyo \& P.V. Garcia 88 (USZ).

Distribuição geográfica: Paraguai, Argentina, Uruguai e Brasil (BA, MG, RJ, SP, MT, MS, PR, SC) (Labiak \& Prado 1998).

Pleopeltis hirsutissima se caracteriza pela presença de escamas gonfóides e deltóide-lanceoladas na lâmina. É uma espécie semelhante a $P$. bombycina (Maxon) A. R. Sm., a qual difere por apresentar apenas escamas gonfóides na lâmina.

Ocorre em Floresta Estacional Semidecidual sempre em ambientes sombreados, como epífita ou ocasionalmente terrícola, acima de $900 \mathrm{~m}$ de altitude.

5.3. Pleopeltis squalida (Vell.) de la Sota, Hickenia 3(47):196. 2003 三 Polypodium squalidum Vell., Fl. Flum. 11, tab. 76. 1827.

Figura 3D-E

Plantas terrícolas. Caule longo-reptante $c a .0,6 \mathrm{~mm}$ diâm. com escamas oval-lanceoladas, $c a$. 1,5 mm compr., 
castanho-escuras na porção central e castanho-claras na margem, ápice acuminado, base arredondada, margem levemente erosa; frondes monomorfas, 4,5-6 cm compr., distantes entre si; pecíolo castanho-escuro, $1,5-3 \mathrm{~cm}$ compr., cilíndrico, recoberto por escamas circulares e outras iguais as do caule; filopódio $c a$. 0,5 mm compr.; lâmina pinatissecta, deltóide-lanceolada, 3-4,5 ×1-1,5 cm, coriácea, ápice agudo, base truncada, face adaxial glabra, face abaxial recoberta por escamas ovais, peltadas, imbricadas, castanho-escura na porção central, margem levemente denteada; raque com escamas oval-lanceoladas abaxialmente, face adaxial glabra; costa com escamas iguais as da lâmina; 6-15 pares de segmentos lineares, 5-8 × 1-1,5 mm., ápice obtuso levemente ascendente, os segmentos proximais não reduzidos, perpendiculares a deflexos, aeróforos ausentes; nervuras livres, furcadas, inconspícuas; soros medianos, dispostos em uma fileira entre a margem e a costa dos segmentos; paráfises ausentes; esporângios glabros; esporos reniformes, verrucosos.

Material examinado: BRASIL. MATo Grosso DO Sul: Corumbá, Morro Urucum, 19¹1'15” S, 57³4'53” W, 29-V-1999, E.L.M. Assis et al. 10 (COR), Idem, Morro Urucum, 7-VI-2001, E.L.M. Assis et al. 207 (COR, MBM, SP, UPCB); Idem, Estrada Parque, Faz. São João, 19¹0'02" S, 57³3’31” W, 12-VI-2001, E.L.M. Assis et al. 236 (COR, MBM, UPCB).

Material adicional examinado: BOLÍVIA. SANTA CRuz: Alto de Mairana, $18^{\circ} 06^{\prime}$ S, 6405’ W, 13-VII-1991, L. Arroyo et al. 48 (USZ).

Distribuição geográfica: Bolívia, Paraguai, Argentina, Uruguai e Brasil (ES, MS, MG, RJ, SP, PR, SC,RS) (Sota 1960 - em parte).

Pleopeltis squalida se caracteriza pelo pequeno tamanho da lâmina (até 4,5 cm compr.) dentre as espécies densamente escamosas da região. Espécie muito próxima a Polypodium polypodioides (L.) Watt. var. burchellii (Baker) Weatherby, a qual difere pelo tamanho maior da lâmina (até $15 \mathrm{~cm}$ compr.) e as escamas do caule fimbriadas. Sota (1960) distingüe estes dois táxons ainda pelas escamas da lâmina, denteadas nesta última.

Muito comum em Floresta Estacional Semidecidual e Decidual, como epífita no dossel da floresta, acima de $700 \mathrm{~m}$ de altitude.

6. Serpocaulon A. R. Sm., Taxon 55(4):924. 2006. Tipo: Polypodium loriceum L. (= Serpocaulon loriceum (L.) A. R. Sm.)

Plantas epífitas, rupícolas ou terrícolas. Caule horizontal, longo-reptante, raramente ramificado, com escamas clatradas, peltadas, glabras; frondes monomorfas, agrupadas ou distantes entre si; pecíolo curto a longo, estramíneo a castanho-escuro, cilíndrico distalmente e achatado e sulcado na porção distal, glabro ou com escamas; lâmina pinatífida, pinatissecta ou 1-pinada, ramamente simples, coriácea, oblonga a lanceolada, glabra, pubescentes ou com escamas esparsas; raque e costa glabras, pubescentes ou com escamas esparsas; segmentos deltóide-lanceolados, margem inteira; nervuras regularmente anastomosadas, com uma vênula inclusa, livre; soros arredondados, surgindo no ápice das nervuras inclusas, em 1-10 séries entre a costa e a margem da lâmina; paráfises presentes ou ausentes; esporângios glabros; esporos bilaterais, verrucosos ou tuberculados.

6.1. Serpocaulon vacillans (Link) A. R. Sm., Taxon 55:928. $2006 \equiv$ Polypodium vacillans Link, Hort. Berol. 2:97. 1833.

Figura 3L-O

Plantas terrícolas. Caule curto-reptante, $c a .8 \mathrm{~mm}$ diâm., com escamas oval-lanceoladas, $c a$. 2 mm compr., castanho-escuras na porção central e castanho-claras na margem, ápice acuminado, peltadas, base arredondada, margem inteira; frondes monomorfas, $11-80 \mathrm{~cm}$ compr., distantes entre si; pecíolo estramíneo, 5-25 cm compr., sulcado, glabro; filopódio $c a .7 \mathrm{~mm}$ compr.; lâmina pinatissecta, deltóide-lanceolada $6-55 \mathrm{~cm}$ compr. $\times$ 5-20 cm larg., herbácea, ápice pinatífido, face adaxial glabra, face abaxial com esparso tricomas castanhoclaros; raque e costa glabras ou com esparsos tricomas iguais aos da lâmina e com escamas lineares, esparsas; segmentos lanceolados, 3-10 cm compr. $\times 0,5-1,5 \mathrm{~cm}$ larg., ápice agudo levemente ascendente, segmentos basais não reduzidos; nervuras anastomosadas, com 1-3 séries de aréolas, terminando livres próximas a margem, vênulas inclusas livres, simples; soros medianos dispostos em 1-3 fileiras entre a margem e a costa da lâmina; esporângios glabros; esporos reniformes, verrucosos.

Material examinado: BRASIL. Mato Grosso DO Sul: Corumbá, Morro do Urucum, $19^{\circ} 11^{\prime} 15^{\prime \prime} \mathrm{S}$, 57³4'53" W, 30-VII-1999, E.L.M. Assis \& D. Rodriguez 47 (BHCB, COR); Idem, id., 26-VI-2001, E.L.M. Assis et al. 269 (COR); Idem, id., 1-IV-2004, E.L.M. Assis et al. 462 (COR).

Material adicional examinado: BOLÍVIA. SANTA Cruz: Caballero, a $25 \mathrm{Km}$ de San Juan de Potrero, $17^{\circ} 48^{\prime}$ S, $64^{\circ} 15^{\prime}$ W, 6-VI-1992, T. Killen \& I. Vargas 4076 (USZ).

Distribuição geográfica: Bolívia, Paraguai, Argentina e Brasil (MT, MS, MG, ES, RJ, SP, PR, SC, RS) (Labiak \& Prado - dados não publicados). 
Esta é a única espécie de Serpocaulon encontrada na região, que se caracteriza por apresentar tricomas e escamas lineares no tecido laminar, nervuras anastomosadas em até 3 fileiras em ambos os lados da costa. Esta espécie é semelhante a S. latipes (Langsd. \& Fisch.) A. R. Sm., a qual difere por não apresentar tricomas no tecido laminar.

Esta espécie foi encontrada ocorrendo sempre acima de $600 \mathrm{~m}$ de altitude. Em ambientes florestais a fronde atinge até $80 \mathrm{~cm}$ de comprimento e as escamas do caule estão sempre presentes, enquanto que em campos de altitude (1.060 m alt.) não passa de $20 \mathrm{~cm}$ compr. e as escamas são geralmente decíduas, deixando apenas cicatrizes no caule.

Agradecimentos - À Capes, pela bolsa de mestrado concedida ao primeiro autor. Ao curso de Pós-graduação em Botânica da UFPR e à Universidade Federal do Mato Grosso do Sul, pelo apoio à realização do presente estudo; e aos curadores dos herbários COR, SP e USZ, que disponibilizaram suas coleções. Dr. Jefferson Prado contribuiu com importantes comentários a este artigo.

\section{Referências bibliográficas}

ADAMOLI, J. 1982. O Pantanal matogrossense e suas relações fitogeográficas com o Cerrado e discussão sobre o conceito de complexo do Pantanal. In Anais do $32^{\circ}$ Congresso Nacional de Botânica, Sociedade Botânica do Brasil, Teresina, p.109-119.

ATHAYDE FILHO, F.P. \& WINDISCH, P.G. 2003. Análise da Pteridoflora da Reserva Biológica Mário Viana, Município de Nova Xavantina, Estado de Mato Grosso (Brasil). Bradea 9:67-76.

BARROS, I.C.L., SILVA, M.R.P., SANTIAGO, A.C.P. \& XAVIER, S.R.S. 2004. Os gêneros Campyloneurum, Dicranoglossum, Niphidium, Pecluma e Pleopeltis (Polypodiaceae - Pteridophyta) para a região Nordeste Setentrional brasileira. Bradea 10:35-64.

BORTOLOTTO, I.M., DAMASCENO JÚNIOR, G.A. \& ISQUIERDO, S.W.G. 1996. Caracterização das unidades fitofisionômicas da microbacia da Baia Negra, Corumbá e Ladário, MS. In Segundo Simpósio sobre Recursos Naturais e Sócio-econômicos do Pantanal - Manejo e Conservação. Embrapa-Pantanal, Corumbá, p.60-64.

CADAVID-GARCIA, E.A. 1984. O clima no Pantanal MatoGrossense. Embrapa/Uepae, Corumbá.

EVANS, A.M. 1969. Interspecific relationships in the Polypodium pectinatum-plumula complex. Annals of the Missouri Botanical Garden 55:193-293.
ISQUIERDO, S.W.G. 1997. Análise Integrada da sub-bacia da Lagoa Negra-MS. Dissertação de mestrado, Universidade de São Paulo, São Paulo.

KESSLER, M. \& SMITH, A.R. 2005. Seven new species, 13 new combinations, and one new name of Polypodiaceae from Bolivia. Candollea 60:271-288.

LABIAK, P.H. 2005. Polypodiaceae. In Flora do Distrito Federal, Brasil (T.B. Cavalcanti \& A.E. Ramos, eds.). . Embrapa, Brasília, p.161-181.

LABIAK, P.H. \& PRADO, J. 1998. Pteridóditas epífitas da Reserva Volta Velha, Itapoá-Santa Catarina, Brasil. Boletim do Instituto de Botânica 11:1-79.

LELLINGER, D.B. 1988. Some new species of Campyloneurum and a provisional key to the genus. American Fern Journal 78:14-34.

MICKEL, J.T. \& SMITH, A.R. 2004. The Pteridophytes of Mexico. Memoirs of the New York Botanical Garden. NYBG Press, New York.

PICHI-SERMOLLI, R.E.G. 1996. Authors of scientific names in Pteridophyta. Royal Botanic Gardens, Kew.

SEHNEM, A. 1970. Polipodiáceas. In Flora ilustrada catarinense. (R. Reitz, ed.). Herbário Barbosa Rodrigues, Itajaí, p.1-173.

SMITH, A.R., PRYER, K.M., SCHUETTPELZ, E., KORALL, P., SCHNEIDER, H. \& WOLF, P.G. 2006. A classification for extant ferns. Taxon 55:705-731.

SOTA, E.R. 1960. Polypodiaceae e Grammitidaceae argentinas. Opera Lilloana 5:1-231.

SOTA, E.R. 1973. A new species of Microgramma from Argentina. American Fern Journal 63:61-64.

WINDISCH, P.G. 1975. Contribuição ao conhecimento das pteridófitas da Serra Ricardo Franco. Bradea 2:1-4.

WINDISCH, P.G. 1985. Pteridófitas do Estado de Mato Grosso - considerações gerais e chave para famílias. Bradea 4:180-187.

WINDISCH, P.G. 1994. Pteridófitas do Estado de Mato Grosso: Gleicheniaceae. Bradea 6:304-311.

WINDISCH, P.G. 1995. Pteridófitas do Estado de Mato Grosso: Marattiaceae. Bradea 6:396-399.

WINDISCH, P.G. 1996. Pteridófitas do Estado de Mato Grosso: Hymenophyllaceae. Bradea 6:400-423.

WINDISCH, P.G. 1997. Pteridófitas do Estado de Mato Grosso: Psilotaceae. Bradea 8:57-60.

WINDISCH, P.G. 1998. Pteridófitas do Estado de Mato Grosso: Osmundaceae. Bradea 8:107-110.

WINDISCH, P.G. \& NONATO, F.R. 1999. Pteridófitas do Estado de Mato Grosso, Brasil: Vittariaceae. Acta Botanica Brasilica 13:290-297.

WINDISCH, P.G. \& TRYON, R.M. 2001. The Serra Ricardo Franco (State of Mato Grosso, Brazil) as probable migration route and its present fern flora. Bradea 8:267-276. 